Volume 45, Supplementary Issue (S1), p. 257-266, October 2017

OFaculty of Veterinary Medicine, Zagazig University, 44511, Egypt

DOI: 10.21608/zvjz.2017.29245.

\title{
Ameliorative effect of Phoenix dactylifera on adverse effects of Linezolid in rats
}

Elsayed A. Abdel Aziz, Sameh M. El-Nabtity and Mahmoud A.A. Said*

Pharmacology Department, Faculty of Veterinary Medicine, Zagazig University, 44511, Egypt

\begin{abstract}
Linezolid is one of the oxazolidinone antibiotics that is used to treat methicillin resistant staphylococcus aureus (MRSA) \& vancomycin resistant Staphylococcus aureus. This study aimed to investigate the adverse effects of linezolid on bone marrow and, kidneys and their counteraction by using Phoenix dactylifera methanolic extract in rats. It was found that oral administration of linezolid ( $100 \mathrm{mg} / \mathrm{kg}$ body weight) for 14 successive days induced a significant decrease in hemoglobin content $(7.88 \pm 0.18 \mathrm{~g} / \mathrm{L})$ on the first day post-treatment, significant increase in serum urea $(59.75 \pm 0.85)$ and creatinine $(1.89 \pm 0.04)$ on the $14^{\text {th }}$ day post- treatment. The concurrent oral administration of Phoenix dactylifera methanolic extract $(1000 \mathrm{mg} / \mathrm{kg}$ body weight) and linezolid (100 mg/kg body weight) for the same period corrected the damaging effects of linezolid of the hemoglobin content, urea, creatinine of treated rats. It was concluded that methanolic extract of phoenix dactylifera clearly ameliorated these damaging effects of linezolid.
\end{abstract}

Key words: Phoenix dactylifera, Linezolid, urea, creatinine, brain and bone marrow

\section{Introduction}

The oxazolidinones represent a new synthetic class of anti- bacterial agents with activity against gram-positive organisms [1].

Studies have shown that the oxazolidinones LZD and eperezolid are active against MRSA, penicillin-resistant Streptococcus pneumoniae, and VRE [2]. Linezolid is entering phase III clinical trials as a therapeutic agent that is effective against skin infections, bacteremia, and pneumonia caused by gram-positive pathogenic bacteria, the antimicrobial activities of the oxazolidinones were first described by scientists at Dupont de Nemours Co., Inc, USA [3]. Resistance to linezolid is extremely rare [4].

Linezolid was discovered in the 1990s and first approved for use in 2000. It was the first commercially available 1, 3-oxazolidinone antibiotic, although others are in development. As a protein synthesis inhibitor, it stops the growth of bacteria by disrupting their production of proteins, that is, a bacteriostatic agent, not bactericidal. Although many antibiotics work this way, the exact mechanism of action of linezolid appears to be unique in that it blocks the initiation step of protein production, and not one of the later steps [5].

In Japan, the use of LZD for MRSA infections was approved in April 2006.
Because the mechanism of action of LZD differs from that of current protein synthesis inhibitors, it is considered to have no crossresistance with existing antimicrobial agents [6]. Data on longer-term use are limited, but serious neuropathies (e.g., peripheral and optic neuropathies), myelosuppression, and hyperlactatemia have been observed [7], and are considered to be related to the inhibition of mitochondrial protein synthesis [8].

Phoenix dactylifera is also known as date palm. It is a monocotyledon plant within the palm tree family and they can be found mostly in the North Africa and Middle East region [9]. They are among a few plants that could survive the harsh arid environment and thus is highly regarded for the nutritional value that the palm tree fruit provides [9]. In these arid regions where foods are scarce, date palm serves as a good food source as they are rich in carbohydrates and they have even become a part of Arabian diet. Aside from a common food source, date palm fruits have been used traditionally to treat various types of ailments and it has been regarded that consumption of the fruit is good for health [10].

Traditional medicines are gaining importance and nowadays are being studied to find the scientific basis of their therapeutic actions. The use of herbal medicine has become increasingly popular worldwide 
especially in the Asian and African countries. The various parts of Phoenix dactylifera are widely used in traditional medicine for the treatment of various disorders which include memory disturbances, fever, and inflammation [11]. Muslims believe that "He who eats seven dates every morning will not be affected by poison or magic on the day he eats them" [12].

The aim of this study is to investigate the possible adverse effects of linezolid on different biological functions in rats, and to find out the possible role of phoenix dactylifera methanolic extract in counteracting these possible adverse effects.

\section{Material and method}

\section{Drugs}

- Linezolid ® (Global napi, Egypt), available as tablets (600 mg/tablet)

- Dose: 100 mg/kg b.wt

- Tween 80 (Al-Gomhoria Co. Ltd, Egypt).

- Methyl alcohol (Al-Gomhoria Co. Ltd, Egypt).

Phoenix dactylifera (Siwa oasis, Egypt).

Solubility It is moderately water-soluble (approximately $3 \mathrm{mg} / \mathrm{mL}$ ), with a $\log \mathrm{P}$ of 0.55 and soluble in $1 \%$ Tween 80 [13].

Phoenix dactylifera fruits: Dose: 1000 $\mathrm{mg} / \mathrm{Kg}$ (as $25 \%$ solution) [14].

\section{Experimental Animals}

Forty eight male albino rats weighing 180$200 \mathrm{gm}$ were used in this experiment. They were left to acclimatize in the laboratory of the Pharmacology Department for two weeks. They were given clean tap water ad libitum and balanced ration.

\section{Methods}

\section{Method of methanolic extraction of phoenix dactylifera fruits}

$1 \mathrm{Kg}$ of fresh fruits of PD and pits were prepared and the fresh PDFs seeds were removed. The known weight of FPDFs was soaked in $1 \mathrm{~L}$ methanol (79\%) and left for three hours, then the mixture was blended in a stainless steel blender and the blended mixture was sieved twice by narrow mesh stainless steel sieve and the sieved part was then added to $2 \mathrm{~L}$ of methyl alcohol $79 \%$. The mixture was then filtered through sterile absorbed gauze. The residual part of dates was soaked in 3 liters of methanol $79 \%$ and left for 2 hours at $20^{\circ} \mathrm{C}$, and then reblended and refrigerated using the clean gauze. The filtrate was added to the previous prepared filtrate and the residual non filtered part was weighed and discarded. The clean part of the supernatant was put in the rotary evaporator and adjusted to $42^{\circ} \mathrm{C}$, then left for methanol to be evaporated. Finally, the resultant crude dates methanolic extract was then measured, weighed \& kept in the laboratory refrigerator till needed to be administered orally to male albino rats.

\section{Experimental design}

Forty eight rats were distributed into four equal groups. (Each of 12 animals). The first group was left as control and was given tween 80 orally using the stomach tube daily for 14 consecutive days. The second group was given $0.5 \mathrm{ml}$ of linezolid suspension $4 \%$ in tween 80 orally daily for 14 consecutive days. The third group received $0.5 \mathrm{ml}$ of linezolid suspension $4 \%$ (100mg/kg body weight) followed by $1 \mathrm{ml}$ of Phoenix dactylifera methanolic extract using the stomach tube daily for 14 consecutive days. The rats in the last group were given $1 \mathrm{ml}$ of Phoenix dactylifera methanolic extract daily for 14 consecutive days.

Sampling: blood samples were collected in clean Wassermann tubes with EDTA as at $1^{\text {st }}$, $7^{\text {th }}$, and $14^{\text {th }}$ day post treatment to be used for hematological studies. After that, rats were dissected out and femur bones were taken and kept on $10 \%$ formalin at the same periods to be used for histopathological study

\section{Hematological studies}

CBC was carried out according to Sysmex ${ }^{\circledR}$ automated cell counter [15].

\section{Biochemical study}

Determination of serum urea [16]. Determination of serum creatinine [17]

\section{Histopathological studies}

Histopathological examinations were carried out according to [18]. Sections were 
stained with hematoxylin for 5-10 minutes, and then washed with running water for 5-10 minutes [19].

\section{Statistical Analysis}

Data were analyzed using computerized SPSS programs version 21 (2001). The results were expressed as Mean \pm S.E.M (Standard error of mean). The total variation was analyzed by performing one-way analysis of variance (ANOVA). Duncan test was used for determining significance. Probability levels of less than 0.05 were considered significant [20].

\section{Results \\ 1-Hematological results \\ Hemoglobin content}

It was clear from Table (1) that the administration of LZD and MEPD and their combination for 14 days displayed nonsignificant changes during the entire period of the study compared with control group except with LZD alone after first day and its combination with MEPD after seven days post treatment which showed a significant decrease and increase $(\mathrm{P}<0.05)$ respectively compared to control group and revealed that the administration of various treatments daily for 14 days to male albino rats in their recommended doses afforded non-significant changes in TLC except with linezolid which afforded a significant increase $(\mathrm{P}<0.05)$ along the entire period of the study compared with control group.

Table (1): Effects of oral administration of Linezolid (100mg/Kg body wt), Phoenix dactylifera methanolic extract $(1000 \mathrm{mg} / \mathrm{kg}$ body $\mathrm{wt})$ and their combination given daily for 14 successive days on $\mathrm{Hb}$ content $(\mathrm{g} / \mathrm{L})$ and TLC $(\mu \mathrm{l})$ of rat. (Mean \pm SE) $(\mathrm{n}=4)$

\begin{tabular}{|c|c|c|c|c|c|c|}
\hline \multirow[b]{2}{*}{$\begin{array}{l}\text { Period } \\
\text { Group }\end{array}$} & \multicolumn{3}{|c|}{$\begin{array}{c}\text { Hemoglobin content }(\mathrm{g} / \mathrm{L}) \\
\text { Time post-treatment }\end{array}$} & \multicolumn{3}{|c|}{$\begin{array}{c}\text { TLC }(\mu \mathrm{l}) \\
\text { Days Post } \text {-treatment }\end{array}$} \\
\hline & $1^{\text {st }}$ day & $7^{\text {th }}$ day & $14^{\text {th }}$ day & $1^{\text {st }}$ day & $7^{\text {th }}$ day & $14^{\text {th }}$ day \\
\hline $\begin{array}{l}\text { Control } \\
\text { LZD }\end{array}$ & $\begin{array}{c}12.93 \pm 0.36^{\mathbf{b}} \\
7.88 \pm 0.18^{\mathbf{c}}\end{array}$ & $\begin{array}{l}12.93 \pm 0.3^{\mathbf{b}} \\
15.30 \pm 0.4^{\mathrm{a}}\end{array}$ & $\begin{array}{l}13.40 \pm 0.6^{\mathrm{a}} \\
13.10 \pm 0.1^{\mathrm{a}}\end{array}$ & $\begin{array}{l}9.60 \pm 1.20^{\mathbf{b}} \\
17.83 \pm 0.5^{\mathbf{a}}\end{array}$ & $\begin{array}{l}9.60 \pm 1.20^{\mathbf{b}} \\
17.78 \pm 0.7^{\mathrm{a}}\end{array}$ & $\begin{array}{l}11.33 \pm 0.59^{\mathrm{b}} \\
15.40 \pm 0.76^{\mathrm{a}}\end{array}$ \\
\hline $\begin{array}{c}\text { LZD+ } \\
\text { PD }\end{array}$ & $13.55 \pm 0.27^{\mathrm{ab}}$ & $15.78 \pm 0.38^{\mathrm{a}}$ & $14.45 \pm 0.32^{\mathrm{a}}$ & $12.00 \pm 0.56^{\mathbf{b}}$ & $12.08 \pm 0.05^{\mathbf{b}}$ & $12.70 \pm 0.83^{\mathrm{ab}}$ \\
\hline PD & $14.28 \pm 0.35^{\mathrm{a}}$ & $12.53 \pm 0.24^{b}$ & $13.83 \pm 0.50^{\mathrm{a}}$ & $11.10 \pm 0.43^{\mathbf{b}}$ & $9.56 \pm 1.30^{\mathbf{b}}$ & $11.48 \pm 0.89^{b}$ \\
\hline
\end{tabular}

Means within the same column carrying different superscripts are significantly different at $\mathrm{P}<0.05$.

\section{Serum urea}

Table (2) revealed that the oral administration of LZD and its combination with MEPD in their recommended doses and time elicited a significant increase in serum urea along the entire period of the study except after 14 days with the combination of both LZD and MEPD which showed a nonsignificant change compared with control group. Whereas, the administration of MEPD alone induced non-significant changes when compared with control group along the entire period of the study and a significant decrease when compared with LZD or its combination after $7^{\text {th }}$ and $14^{\text {th }}$ days post treatment. Also, it demonstrated that various treatments given daily for 14 days in their recommended doses afforded a significant increase in serum creatinine after the first day post treatment except MEPD alone which produced a slight increase.

Whereas, various treatment induced nonsignificant changes when compared with control group except combination of LZD and MEPD which induced a significant decrease compared with control group and linezolid treated group. Whereas, after 14 days various treatments induced a significant increase when compared with control group except MEPD alone which induced a non-significant change with control group and a significant decrease when compared with LZD alone and its combination with MEPD. 
Table 2. Effects of oral administration of Linezolid $(100 \mathrm{mg} / \mathrm{Kg}$ body wt), Phoenix dactylifera $(1000 \mathrm{mg} / \mathrm{kg}$ b.wt) and their combination given for 14 successive days on serum urea and serum creatinine $(\mathrm{mg} / \mathrm{dl})$ of rat. $($ Mean $\pm \mathrm{SE})(\mathrm{n}=4)$ :

\begin{tabular}{|c|c|c|c|c|c|c|}
\hline & \multicolumn{3}{|c|}{ Serum Urea (mg/dl) } & \multicolumn{3}{|c|}{ Serum Creatinine (mg/dl) } \\
\hline & \multicolumn{3}{|c|}{ Time-post treatment } & \multicolumn{3}{|c|}{ Time-post treatment } \\
\hline & $1^{\text {st }}$ day & $7^{\text {th }}$ day & $14^{\text {th }}$ day & 1d & $7 d$ & 14d \\
\hline Control & $27.00 \pm 0.71^{\mathbf{b}}$ & $27.00 \pm 0.71^{\mathbf{b}}$ & $45.50 \pm 1.04^{\mathbf{b c}}$ & $0.75 \pm 0.06^{\mathbf{b}}$ & $0.75 \pm 0.06^{\mathrm{a}}$ & $0.85 \pm 0.02^{\mathrm{c}}$ \\
\hline LZD & $36.75 \pm 1.44^{\mathrm{a}}$ & $42.68 \pm 1.38^{\mathrm{a}}$ & $59.75 \pm 0.85^{\mathrm{a}}$ & $1.23 \pm 0.04^{\mathrm{a}}$ & $0.74 \pm 0.01^{\mathrm{a}}$ & $1.89 \pm 0.04^{\mathrm{a}}$ \\
\hline LZD+ PD & $37.75 \pm 2.95^{\mathrm{a}}$ & $44.65 \pm 5.01^{\mathrm{a}}$ & $48.75 \pm 1.11^{\mathrm{b}}$ & $1.16 \pm 0.09^{\mathrm{a}}$ & $0.57 \pm 0.02^{b}$ & $1.35 \pm 0.02^{b}$ \\
\hline PD & $31.00 \pm 2.12^{\mathbf{a b}}$ & $27.77 \pm 0.83^{\mathbf{b}}$ & $41.00 \pm 1.58^{\mathrm{c}}$ & $0.97 \pm 0.10^{\mathbf{a b}}$ & $0.75 \pm 0.06^{\mathbf{a}}$ & $0.96 \pm 0.05^{\mathbf{c}}$ \\
\hline
\end{tabular}

Means within the same column carrying different superscripts are sig. different at $\mathrm{P}<0.05$.

\section{Histopathological results}

\section{Bone marrow}

The bone marrow section of the control group showed numerous megakaryocytes with white and red blood cells. After seven days post-treatment the bone marrow section showed hypocellular bone marrow elements with linezolid alone. But the combination of both linezolid and methanolic extract of phoenix dactylifera, the bone marrow section showed moderate increase in the bone marrow elements and scattered fat cells. Whereas, normal bone marrow was normal cellularity and numerous megakaryocytes surrounded by white and red blood cell elements was observed as a result of treatment with Phoenix alone after the seventh day post-treatment (Figure 1A-D).

\section{Brain}

Normal brain tissue from control group showed normal neuron cells surrounded by neurological fibers with elongated vascular space filled with red blood cells. After one day post-treatment with linezolid, the brain tissue showed aggregates of inflammatory cells surrounding dilated vascular space, while the group treated with the combination of linezolid and methanolic extract of phoenix dactylifera showed mild aggregates of inflammatory cells. Whereas, the group treated with methanolic extract of phoenix dactylifera revealed normal neuron cells and neurofillary material after the first day post-treatment (Figure 1E-H).

\section{Kidney}

The kidney section of the control group showed normal renal glomeruli and renal tubules. The renal tissue showed moderately dilated congested vascular space and mild aggregates of inflammatory cells in between glomeruli and renal tubules at day seven posttreatment with linezolid alone. Whereas, the combination of both linezolid and methanolic extract of phoenix dactylifera led to absence of inflammatory cells with the return of renal tissue to its normal state at day seven posttreatment. Whereas, 7 days post-treatment with phoenix dactylifera, the renal tissue showed normal structure (Figure 1I-L). 

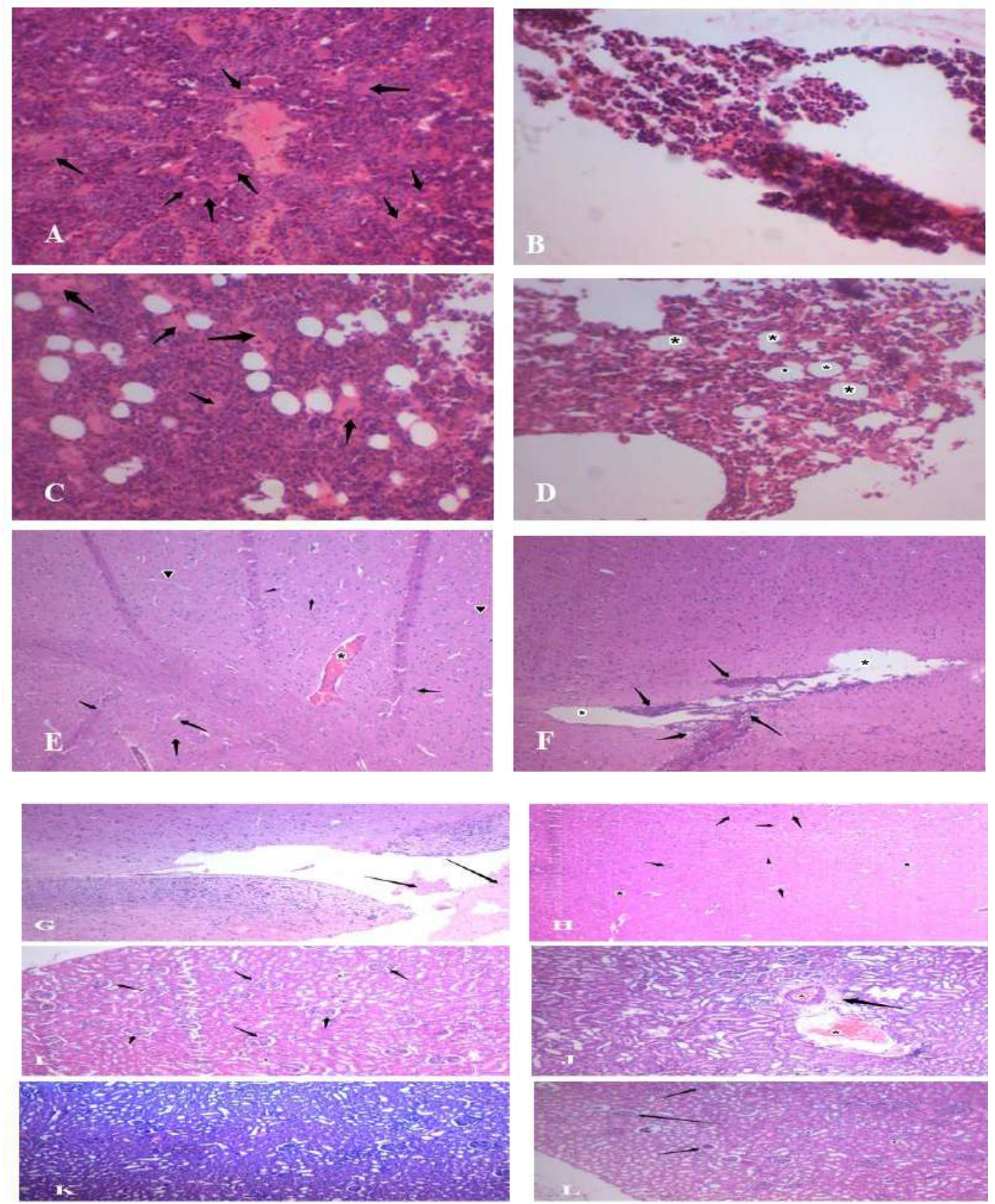

Figure 1 A. Photomicrograph of normal bone marrow of control group showing numerous megakarycotes $\uparrow$ with white and red blood cells elements. (H \& E X400). B. Photomicrograph of bone marrow from rats 7 days post-treatmet treated with linezolid showing hypocellular bone marrow elements. (H \& E X 400). C. Photomicrograph of normal bone marrow from rats one day post-treatment with phoenix showing normal cellularity of the bone marrow with numerous megakaryocytes $\uparrow$ surrounded by white blood cell and red blood cell elements. (H \& E X 400). D. Photomicrograph of bone marrow treated with linezolid and phoenix 7 days post treatment showing moderate increase in the bone marrow elements with scattered fat cells * (H \& E X 200). E. Photomicrograph of normal brain tissue from control group showing normal neuron cells $\uparrow$ surrounded by neurological fibers with elongated vascular space filled with red blood cells *. (H \& E X 200). F. Photomicrograph of brain tissue treated with linezolid at the first day post treatment showing aggregates of inflammatory cells $\uparrow$ surrounding dilated vascular space *. (H \& E X 200). G. Photomicrograph of brain tissue from rats treated with linezolid and phoenix at day one post-treatment showed mild aggregates of inflammatory cells $\uparrow$. (H \& E X 200). H. Photomicrograph of brain tissue from rats at day one post-treatment with phoenix showing normal neuron cells $\uparrow$ and neurofillary material *. (H \& E X 200). I. Photomicrograph of normal rat kidney of control group showing renal glomeruli $\uparrow$ and renal tubules *. (H \& E X 200). J. Photomicrograph of kidney from rats seven days post-treatment with linezolid showing moderately dilated congested vascular space * and mild aggregates of inflammatory cells $\uparrow$ in between the glomeruli and tubules. (H \& E X 200). K. Photomicrograph of kidney treated with linezolid and phoenix seven days post treatment showing normal glomeruli $\uparrow$ and tubules * (H \& E X 200). L. Photomicrograph of kidney treated with phoenix showing normal glomeruli $\uparrow$ and tubules *. (H \& E X 200). 


\section{Discussion}

Linezolid is an oxazolidinone antimicrobial drug active against antibiotic-resistant Grampositive bacteria including methicillinresistant Staphylococcus aureus (MRSA) and vancomycin-resistant enterococci [21]. Its high oral bioavailability provides a definite economic advantage compared with other MRSA therapeutic options, allowing earlier hospital discharge and reducing out-patient therapy cost. Linezolid is well-tolerated with nausea, vomiting, diarrhea and headache being the most commonly reported side effects. Bone marrow suppression and neuropathies may occur in patients taking this antibiotic for more than two weeks [22].

The present study was carried out to evaluate the adverse effects of therapeutic doses of linezolid in tween 80 for fourteen consecutive days on adult male albino rats $(100 \mathrm{mg} / \mathrm{kg}$ bwt.) and to use the methanolic extract of Phoenix dactylifera fruits in a new trial to possibly counteract the undesirable effects of linezolid. Further approach was designed to study the pharmacological effects of these drugs on some hematological parameters. Histopathological picture and further approach for detecting any dysfunction in bone marrow femur bones was performed.

On $\mathrm{Hb}$. content, a significant decrease was observed after one day post-treatment with linezolid similar results were previously recorded by Birmingham et al., [23] and MacDougall and Chambers [24], who reported that one of the adverse effects induced by linezolid is anemia. The TLC was significantly increased during the entire period of the study which might be due to posterior leuco encephalopathy induced by linezolid [25]. Our findings were also incompatible with Ager and Gould [26] who recorded that oral administration of linezolid at a dose of $600 \mathrm{mg}$ twice daily post-administration induced leucopenia and thrombocytopenia after 28 days in human. It needs further investigation to explain the cause of this leukocytosis. These findings were supported by the histpathological changes in the bone marrow which revealed hypocellularity reverting them to their normal state as concluded by Arshad et al., [27] who reported that MEPD decreased TLC due to its anti-inflammatory effect.
The obtained results revealed that linezolid in its recommended doses and duration afforded a significant increase in serum urea and creatinine whereas phoenix dactylifera when given in combination with linezolid decreased these elevated levels significantly, reverting them to their normal control values. These results were supported by the histopathological study in this work which revealed that linezolid elicited degenerative changes in the kidney.

Effect of linezolid (100 mg/kg bwt.) orally administered to rats for 14 consecutive days on serum creatinine level showed a significant increase on the fourteenth day post treatment. These results were supported by our histopathological findings shown on the kidney sections. Also, our results agreed with those established by Natsumoto et al., [28] who reported that linezolid increased serum creatinine level in patient received linezolid for 7 weeks and this may be contributed to that linezolid can cause interstitial nephritis after 3 days as reported by Nayak et al., [29]. Upon administration of linezolid and Phoenix dactylifera combination, our recorded results showed a significant decrease in creatinine level, this suggested that Phoenix dactylifera fruits have nephroprotective effect as investigated by Al-Qarawi et al., [30] who studied the effect of an extract of the flesh and pits of Phoenix dactylifera on gentamicininduced nephrotoxicity in rats were effective in reducing the increased serum creatinine. Also, our results informed that linezolid caused a significant increase in the serum urea as shown in figure and table; these results agreed with Ahmed et al., [31] who stated that linezolid mildly elevated urea fourteen days after administration in patients with renal impairment.

Our histopathological outcomes revealed in figure, methanolic extract of Phoenix dactylifera fruits returned the kidney to its normal state and treated its lesion, these results were in accordance with Lin et al., [32] who concluded that the protection of Phoenix dactylifera seeds extract could be attributed to the total phenol/proanthocyanidin content, which can suppress the oxidative stress induced by xenbiotic-generating free radicals with the subsequent restoration of the 
physiological and histological features of the susceptible organs.

Our histopathological findings on the brain section showed aggregates of inflammatory cells and that may be due its high penetration through CSF [33] and may be contributed to the axonal damage to sensory neurons that occurs after linezolid exposure [34]. Linezolid and Phoenix dacylifera combination showed mild aggregates of inflammatory cells. This result agreed with Agbon et al., [35] who concluded that Phoenix dactylifera fruits have neuroprotective effect due to its anti-oxidant properties.

\section{Conclusion}

The current study revealed the oral administration of the therapeutic dose of linezolid to male albino rats for fourteen consecutive days resulted in damaging effects on the bone marrow. It was evident that the concurrent oral administration of Phoenix dactylifera methanolic extract $(1000 \mathrm{mg} / \mathrm{kg}$ bwt.) with linezolid (100 mg/kg bwt.) clearly counteracted the bone marrow damaging effects of linezolid.

\section{Conflict of interest}

The authors declare that they have no conflict of interest.

\section{References}

[1] Brickner S. J.; Hutchinson M. R.; Barbachyn P. R.; Manninen D. A.; Ulanowicz S. A.; Garmon K.C.; Grega S. K.; Hendges D. S.; Toops G. E.; Zurenko F. and Ford C.W. (1996) Synthesis and antibacterial activity of U-100592 and U-100766, two oxazolidinone antibacterial agents for the potential treatment of multidrug-resistant gram-positive bacterial infections: J. Med. Chem. 39:673-679.

[2] Ford C. W.; Hamel J. C.; Wilson D. M.; Moerman J. K.; Stapert D.; Yancey R. J. Jr.; Hutchinson D. K.; Barbachyn M. R. and Brickner S. J. (1996): In vivo activities of U-100592 and U-100766, novel oxazolidinone antimicrobial agents, against experimental bacterial infections. Antimicrob. Agents Chemother. 40(6):1508-1513.

[3] Daly J. S.; Eliopoulos G. M.; Wiley S.; and Moellering R. C., Jr. (1996): Mechanism of action in vitro and in vivo activities of S-6123, a new oxazolidinone compound. Antimicrob. Agents Chemother. 32:13411346.

[4] Tenover F. C.; Arbeit,R. D.; Goering R. V.; Mickelsen P. A.; Murray B. E.; Persing D. H. and Swaminathan, B. (1995): Interpreting chromosomal

DNA restriction patterns produced by pulsed-field gel electrophoresis: criteria for bacterial strain typing. $\mathrm{J}$ Clin Microbiol 33, 2233-2239

[5] Swaney S.M.; Aoki H. and Ganoza M.C. (1998): The oxazolidinone linezolid inhibits initiation of protein synthesis in bacteria. Antimicrob. Agents Chemother. 42(12): 3251-3255.

[6] Gonzales R.D.; Schreckenberger P.C.; Graham M.B.; Kelkar S.; DenBesten K. and Quinn J.P. (2001): Infections due to vancomycin-resistant Enterococcus faecium resistant to linezolid. Lancet 357 (9263):1179.

[7] Di Paolo A.; Malacarne P.; Guidotti E.; Danesi R. and Del Tacca M. (2010): Pharmacological issues of linezolid: an updated critical review. Clin Pharmacokinet; 49:439-47.

[8] Beekmann S.E.; Gilbert D.N. and Polgreen P.M. (2008): Toxicity of extended courses of linezolid: results of an Infectious Diseases Society of America Emerging Infections Network survey. Diagn Microbiol Infect Dis; 62(7):407-410

[9] Baliga M. S.; Bantwal R.; Vittaldas B.; Shaun M. K.; Harshith P. B.; Praveen K. and Vayalil P.K. (2011): A review of the chemistry and pharmacology of the date fruits (Phoenix dactylifera L.) Food Research International 44: 1812-1822.

[10] Mansouri A.; Embarek G.; Kokkalouc E. and Kefalas P. (2005): Phenolic profile and antioxidant activity of the Algerian 
ripe date palm fruit (Phoenix dactylifera). Food Chemistry 89(3): 411420.

[11] Abedi A.; Parviz M.; Karimian S. M. and Rodsari S. (2012): The Effect of Aqueous Extract of Phoenix dactylifera Pollen Grain on Sexual Behavior of Male Rats. J Phys Pharm Adv 2(6): 235-242.

[12] Miller C.J.; Dunn E.V. and Hashim I.B. (2003): The glycemic index of dates and date/yoghurt mixed meals. Are dates 'the candy that grows on trees'? Eur J Clin Nutr 57(4):427-30.

[13] Patel M. I. and Makhija S. J. (2012): Toxicity assessment of Linezolid and the beneficial effects of human erythropoietin in mice. European Journal of Experimental Biology 2 (6):21722181.

[14] Agbon A.N.; Ingbian S.N.; and Dahiru A.U. (2014): Preliminary histological and histochemical studies on the neuroprotective effect of aqueous fruit extract of phoenix dactylifera L. (Date Palm) on atesunate-induced cerebellar damage in wistar rats J. Medicine 1(4), 204-209.

[15] Pekelharing J. M.; Hauss O.; Jonge R.; Lokhoff J.; Sodikromo J.; Spaans M.; Brouwer R.; Lathouder S. and Hinzmann R. (2009): Haematology reference intervals for established and novel parameters in healthy adults. Diagnostic Perspectives. 1: 1-11

[16] Patton C. and Crouch G. (1977): Enzymatic colorimetric determination of urea. Anal. Chem., 49:464-469.

[17] Henry T.J. (1974): Determination of serum Creatinine. Clin. Chem. Principle and Techniques $2^{\text {nd }}$ Ed. Harper and Row Publishers. New York.

[18] Culling C.F. (1974): Handbook of Histopathological and Histochemical techniques. 3rd Ed. Butter worth, London, Boston.
[19] Drury R.A.B and Wallington F.A. (1980): Corleton's Histological Technique 4th Ed. Oxford, New York, Toronto, Oxford university press. 24(11) 1122-1123.

[20] Snedecor, G.W. and Cochran, W.G. (1982): Statistical Methods. $8^{\text {th }}$ ed. Ames, Iowa state University Press., Iowa, USA.

[21] Dresser L.D. and Rybak M.J (1998): The pharmacologic and bacteriologic properties of oxazolidinones, a new class of synthetic antimicrobials. Pharmacotherapy, 18:456-462.

[22] Stevens D.L.; Smith L.G.; Bruss J.B.; McConnell-Martin M.A.; Duvall SE; Todd W.M. and Hafkin B. (2000): Randomized comparison of linezolid (PNU-100766) versus oxacillindicloxacillin for treatment of complicated skin and soft tissue infections. Antimicrob Agents Chemother, 44(12):3408-3413.

[23] Birmingham M. C.; Rayner C. R.; Meager A. K.; Flavin S. M.; Batts D. H. and Schentag J. J. (2003): Linezolid for the treatment of multidrug-resistant, grampositive infections: experience from a compassionate-use program. Clinical Infectious Diseases 36 (2):159-68.

[24] MacDougall C. and Chambers HF. (2011): Protein synthesis inhibitors and miscellaneous antibacterial agents. In: Brunton LL, Chabner BA, Knollmann BC, editors. Goodman and Gilman's The Pharmacological Basis of Therapeutics. 12th ed. New York: McGraw Hill. p.1537-8.

[25] Simon N.; Martin K.; Hagen B.H.; Brigitte S.H. and Stefan S. (2007): Linezolid-Induced Posterior Reversible Leukoencephalopathy Syndrome Arch Neurol. 64(5):746-748

[26] Ager S. and Gould K. (2012): Clinical update on linezolid in the treatment of Gram-positive bacterial infections Infect Drug Resist.5:87-102. 
[27] Arshad H. R.; Salah M A.; Habeeb A.; Ali Y. B.; Sauda S. and Amjad A. k. (2014): Therapeutic effects of date fruits (Phoenix dactylifera) in the prevention of diseases via modulation of antiinflammatory, anti-oxidant and antitumour activity. Int J Clin Exp Med. (3): 483-491.

[28] Natsumoto B., Yokota K., Omata F., and Furukawa K. (2014): Risk factors for linezolid-associated thrombocytopenia in adult patients. J. infection 42(6): 1007-1012.

[29] Nayak S.; Nandwani A., Rastogi A., and Gupta V. (2012): Acute interstitial nephritis and drug rash with secondary to Linezolid Indian J Nephrol. 22(5): 367-369.

[30] Al-Qarawi A. A.; Abdel-Rahman H.; ElMougy S.A.; Mousa H.M; and Badreldin H.Ali (2008): Nephroprotective action of Phoenix dactylifera in GentamicinInduced Nephrotoxicity Pharmaceutical Biology 46(4):227-230.

[31] Ahmed A.F.; Al-Qahtani J. H.; AlYousef H. M.; Al-Said M. S.; AbdelKader E. A.; Al-Sohaibani M. and Syed R. (2015): Proanthocyanidin-Rich Date Seed
Extract Protects Against Chemically Induced Hepatorenal Toxicity. J. Med Food. 18(3): 280-289.

[32] Lin Y.H., Wu V.C., and Tsai I.J. (2006): High frequency of linezolid-associated thrombocytopenia among patients with renal insufficiency. Int $\mathbf{J}$ Antimicrob Agents.; 28:345-351.

[33] Villani P.; Regazzi M.B. and Marubbi F. (2002): Cerebrospinal fluid linezolid concentrations in postneurosurgical central nervous system infections. Antimicrob. Agents Chemother. 46 (3)936-937.

[34] Bobylev I; Maru H.; Joshi A.R. and Lehmann H.C. (2015): Toxicity to sensory neurons and Schwann cells in experimental linezolid-induced peripheral neuropathy. JAntimicrob Chemother. 71(3):685-91

[35] Agbon A.N.; Ingbian S.N.; and Dahiru A.U. (2014): Preliminary histological and histochemical studies on the neuroprotective effect of aqueous fruit extract of phoenix dactylifera L. (Date Palm) on atesunate-induced cerebellar damage in wistar rats J. Medicine 1(4), 204-209. 


\title{
التأثير الواقي لخلاصة التمر على الاثثار الجانبية للينزوليد في الجرذان
}

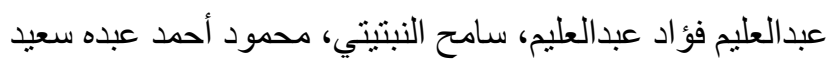

قسم الفارماكولوجيا- كلية الطب البيطري- جامعة الزقازيق

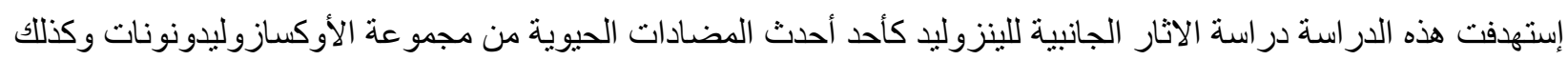

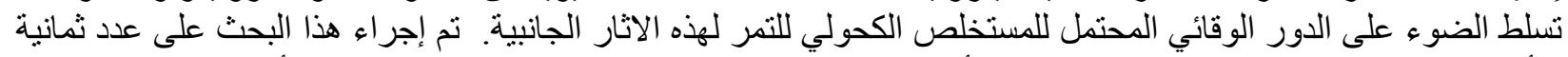

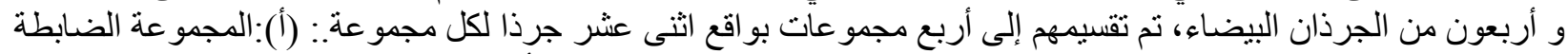

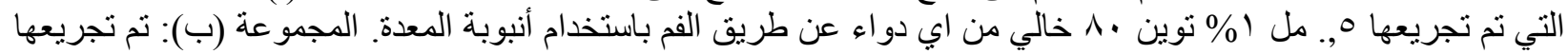

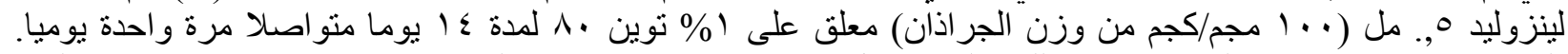

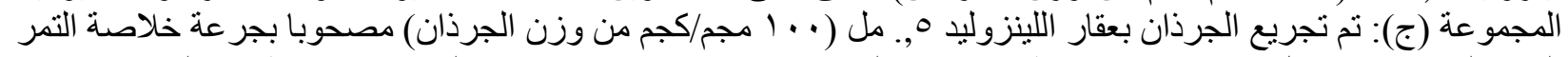

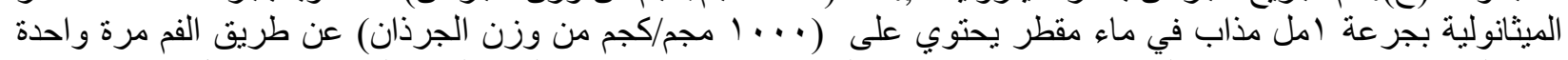

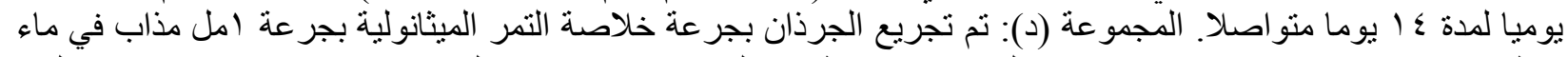

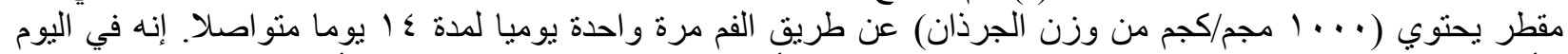

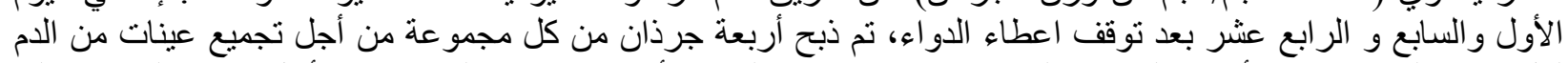

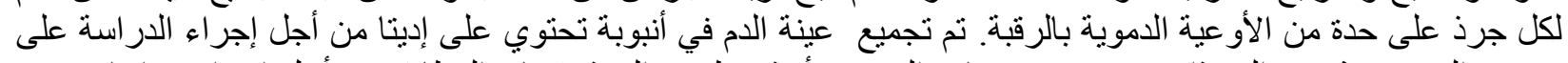

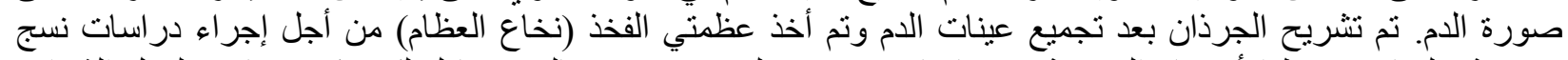

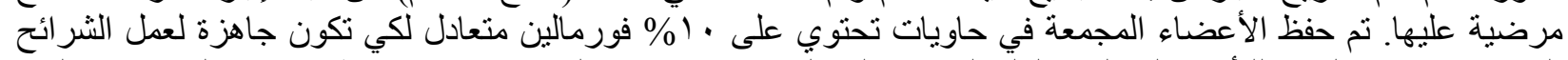

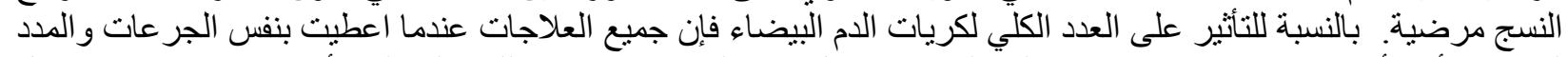

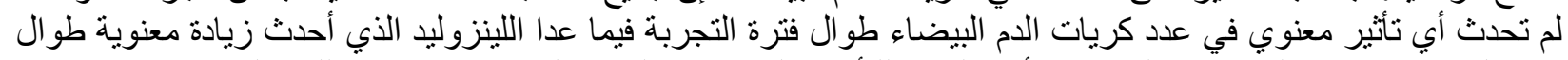

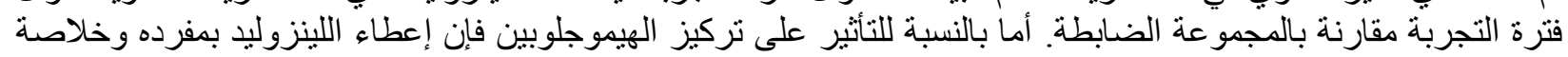

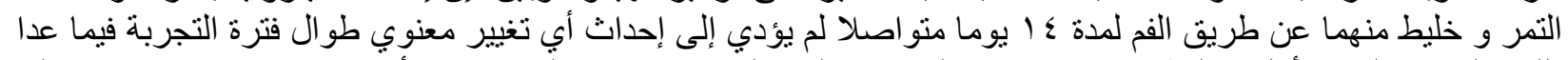

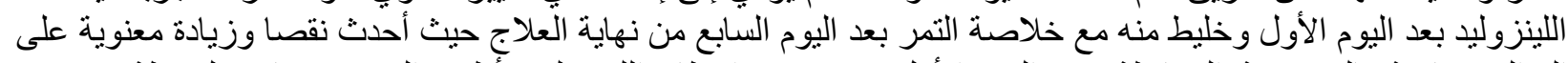

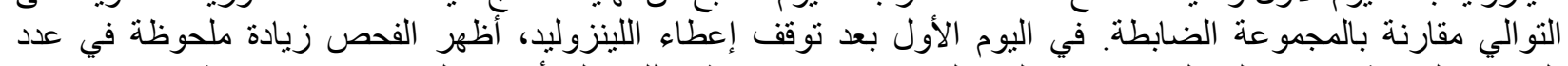

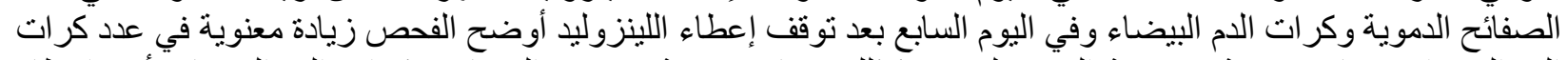

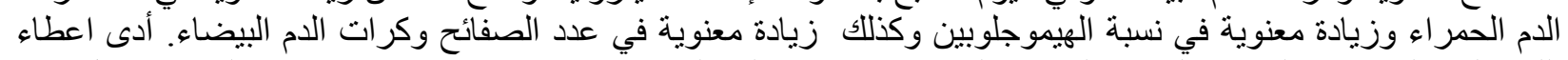

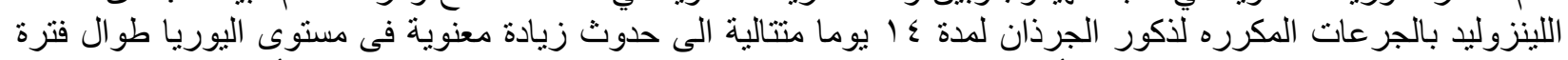

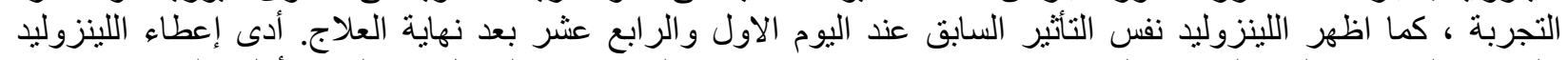

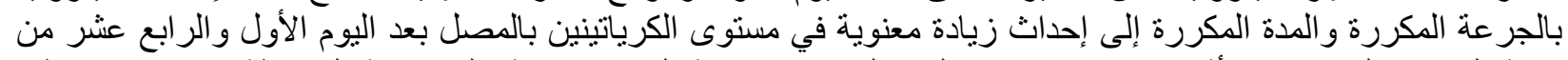

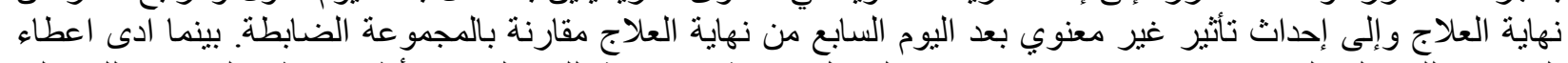

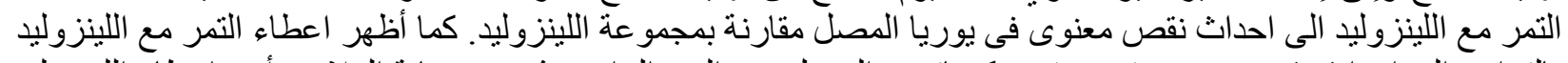

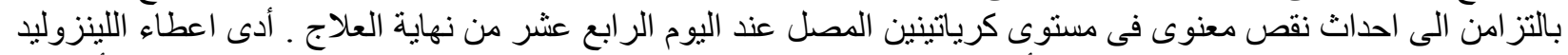

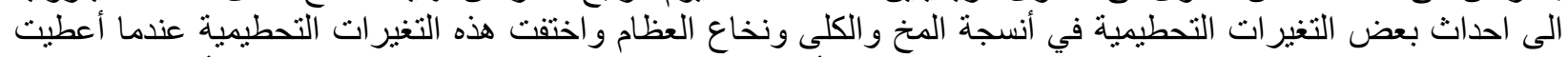

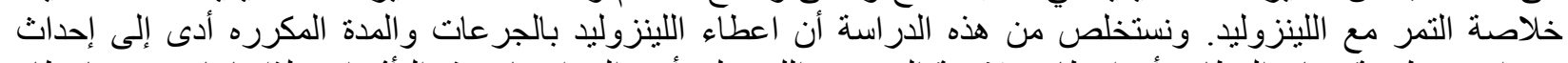

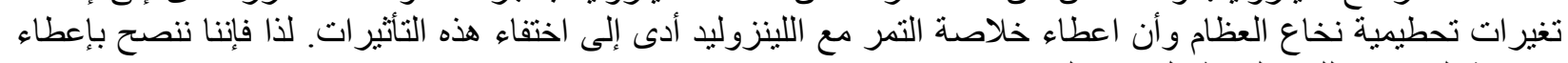
خلاصة التمر مع اللينزوليد طو ال فترة وان اعطاء العلاج. 